\title{
Cloning of new Rhodococcus extradiol dioxygenase genes and study of their distribution in different $R$ hodococcus strains
}

\author{
Leonid A. Kulakov, ${ }^{1}$ Valerie A. Delcroix, ${ }^{1}$ Michael J. Larkin, ${ }^{1}$ \\ Vladimir N. Ksenzenko ${ }^{2}$ and Anna N. Kulakova ${ }^{1}$ \\ Author for correspondence: Leonid A. Kulakov (Questor Centre). Tel: +441232335577 . Fax: +441232 \\ 661462. e-mail: 1.kulakov@queens-belfast.ac.uk
}

\footnotetext{
1 The Questor Centre, David Keir Building, The Queen's University of Belfast, Belfast BT9 5AG, UK and School of Biology and Biochemistry, Medical Biology Centre, The Queen's University of Belfast, Belfast BT9 7BL, UK

2 Institute of Biochemistry and Physiology of Microorganisms, Russian Academy of Science, Pushchino, Moscow region, Russia
}

\begin{abstract}
Four extradiol dioxygenase genes which encode enzymes active against catechol and substituted catechols were cloned from two different Rhodococcus strains, and their nucleotide sequences were determined. A catechol 2,3-dioxygenase gene (edoC) was shown to be identical to the previously described ipbC gene from the isopropylbenzene operon of Rhodococcus erythropolis. Amino acid sequences deduced from the three other genes (edoA, edoB and edoD) were shown to have various degrees of homology to different extradiol dioxygenases. The EdoA and EdoB dioxygenases were classified as belonging to the third family of type I oxygenases and represented two new subfamilies, whereas the EdoD dioxygenase was a type II enzyme. Analysis of six Rhodococcus strains revealed a wide distribution of the above dioxygenase genes. Rhodococcus sp. 11 was shown to harbour all four of the analysed dioxygenase genes. Nucleotide sequences homologous to the edoB gene were present in all of the strains, including $R$. erythropolis NCIMB 13065, which did not utilize any of the aromatic compounds analysed. The latter finding points to the existence of a silent pathway(s) for degradation of aromatic compounds in this Rhodococcus strain.
\end{abstract}

Keywords: Rhodococcus, catechol, dioxygenase, PCR, biodegradation

\section{INTRODUCTION}

Gram-positive bacteria of the genus Rhodococcus demonstrate a remarkable ability to utilize a wide variety of xenobiotic compounds (Finnerty, 1992). However, despite a growing interest in the role of Rhodococcus spp. in the environment, relatively little is known of the genetic determinants which control the biodegradation routes in these micro-organisms and their distribution amongst different strains. Ring cleavage is an important step in the aerobic degradation of aromatic compounds and catechols are typical substrates for such reactions. This cleavage is catalysed by the enzymes belonging to one of two different classes: intradiol or extradiol dioxygenases (Harayama et al., 1992). It is wellestablished that extradiol enzymes with activities against

The GSDB accession numbers for the sequences reported in this paper are L77225 (edoA gene), GSDB:S:1050684 (edoB gene), GSDB:S: 1076510 (edoC gene) and GSDB:S: 1076511 (edoD gene). catechol and substituted catechols are key enzymes in the bacterial degradation of aromatic compounds (Hayaishi, 1974; Harayama et al., 1992). According to the most recent classification, based on a structurevalidated alignment of 38 extradiol dioxygenase sequences and their subsequent phylogenetic analysis, these enzymes form two different types: type I includes 35 dioxygenases belonging to five families and type II includes only two enzymes which show low mutual sequence identity and probably belong to different families (Eltis \& Bolin, 1996). Several extradiol dioxygenase genes from Rhodococcus spp. utilizing biphenyl have been cloned and characterized (Masai et al., 1995; Maeda et al., 1995). It has been shown that multiple $b p h C$ extradiol dioxygenase genes with different structural characteristics may be found in some biphenyl-degrading Rhodococcus strains (Asturias et al., 1994; Maeda et al., 1995).

A number of Rhodococcus biodegrading strains isolated in the Questor microbiology laboratory have been 
shown to degrade aromatic and aliphatic compounds (Larkin \& Day, 1986; Curragh et al., 1994). The aim of this study was to analyse the diversity of dioxygenase genes in Rhodococcus. We present cloning and sequence analysis of Rhodococcus dioxygenase genes from six strains which were isolated as naphthalene, cresol and 1-chloroalkane degraders. This analysis showed that highly homologous dioxygenase genes are probably widely distributed amongst $R$ hodococcus species.

\section{METHODS}

Bacterial strains and plasmids. Escherichia coli strain DH5 $\alpha$ (Sambrook et al., 1989) and plasmid vectors pUC129 (Keen $e t$ al., 1988) and pBluescript $\mathrm{KS}(+)$ were used for the cloning experiments. The $\mathrm{Nah}^{+}$derivative P200 of Rhodococcus rhodochrous NCIMB 13064 (Kulakova et al., 1996) and Rhodococcus sp. NCIB 12038 (Larkin \& Day, 1986) have been described previously. The characteristics of other Rhodococcus strains isolated from soil are presented in Table 1.

Media and growth conditions. Rhodococcus and E. coli strains were propagated in a rich (2YT) or minimal (M9) medium (Miller, 1972). When required, Difco agar $(1.8 \%$, $\mathrm{w} / \mathrm{v}$ ) was added to the medium. When the cultures were grown on minimal agar plates, naphthalene, cresols, toluene, biphenyl, isopropylbenzene and 1-chloroalkanes were added as vapours. Ampicillin $\left(100 \mu \mathrm{g} \mathrm{m}^{-1}\right)$, tetracycline $\left(15 \mu \mathrm{g} \mathrm{m}^{-1}\right)$, IPTG $\left(50 \mu \mathrm{g} \mathrm{ml}^{-1}\right)$ and X-Gal $\left(50 \mu \mathrm{g} \mathrm{ml}^{-1}\right)$ were used for the detection of recombinant plasmids.

DNA techniques. Total DNA from Rhodococcus strains was isolated as described by Kulakova et al. (1995). Recombinant DNA work was done by using standard protocols as described by Sambrook et al. (1989). Restriction of both total DNA and recombinant plasmids was performed using enzymes obtained from Pharmacia, according to the manufacturer's instructions. The Sephaglas BandPrep kit (Pharmacia) was used for the recovery of restriction fragments and PCR products from agarose gels.
DNA fragments were transferred to Z-probe membranes (BioRad) by Southern blotting, as described by Sambrook et al. (1989). The membranes were then treated according to the manufacturer's instructions. Hybridization probes were labelled with $\left[{ }^{32} \mathrm{P}\right] \mathrm{dCTP}$ using an oligolabelling kit (Pharmacia) and hybridization was carried out in $0.25 \mathrm{M} \mathrm{Na}_{2} \mathrm{HPO}_{4}$, $\mathrm{pH} 7 \cdot 2,7 \%(\mathrm{w} / \mathrm{v})$ SDS at $60^{\circ} \mathrm{C}$ for $10-12 \mathrm{~h}$.

Enzyme assays. Cell-free extracts were prepared as described previously (Kulakova et al., 1996). Catechol 2,3-dioxygenase and 3-methylcatechol and 4-methylcatechol 2,3-dioxygenase activities were assayed spectrophotometrically (Gibson, 1971) in $50 \mathrm{mM}$ Tris/ $\mathrm{HCl}$ buffer (pH 7.8), $0.1 \mathrm{mM} \mathrm{DTT,} 10 \%$ glycerol, $10 \%$ ethanol, and 2,3-dihydroxybiphenyl dioxygenase activity was assayed as described by Hauschild et al. (1996). The relative ring cleavage activities were determined from the absorption coefficients of the ring fission products formed from the following substrates: catechol $\left(\lambda_{\max }, 375 \mathrm{~nm}\right.$; $\left.\varepsilon=33000 \mathrm{~cm}^{-1} \mathrm{M}^{-1}\right) ; \quad 3$-methylcatechol $\left(\lambda_{\max }, 388 \mathrm{~nm}\right.$; $\left.\varepsilon=19400 \mathrm{~cm}^{-1} \mathrm{M}^{-1}\right) ; \quad$ 4-methylcatechol $\left(\lambda_{\max }, 382 \mathrm{~nm}\right.$; $\left.\varepsilon=28100 \mathrm{~cm}^{-1} \mathrm{M}^{-1}\right) ; 2,3$-dihydroxybiphenyl $\left(\lambda_{\max }, 434 \mathrm{~nm}\right.$; $\left.\varepsilon=13200 \mathrm{~cm}^{-1} \mathrm{M}^{-1}\right)$. 1,2-Dihydroxynaphthalene dioxygenase activity was measured as described by Patel \& Barnsley (1980) and modified by Kuhm et al. (1991). Relative activities were expressed as percentages of the activity observed in cellfree extracts of DH5 $\alpha$ (pUP25) when catechol was the substrate, which was defined as $100 \%$. Protein concentrations were determined using the BCA assay (Pierce).

Cloning. Total DNA isolated from Rhodococcus strains was digested with EcoRI, BamHI or XhoI restriction endonucleases. The preparations were ligated with plasmid pUC129, digested with the corresponding enzyme and treated with alkaline phosphatase (Pharmacia) according to the manufacturer's instructions. The resulting recombinant plasmids were used to transform $E$. coli DH $5 \alpha$. Clones that expressed catechol 2,3-dioxygenase and/or 3-methylcatechol 2,3-dioxygenase activities were identified by their yellow colour after spraying with a $0 \cdot 1 \mathrm{M}$ solution of corresponding ring cleavage substrate (Zukowski et al., 1983). A Pharmacia kit utilizing exonuclease III and S1 nuclease was used to generate unidirectional deletion derivatives.

\section{Table 1. Substrate utilization by Rhodococcus strains}

Rhodococcus cultures were tested for growth on minimal agar (M9) plates at $30^{\circ} \mathrm{C}$ with the corresponding compound as sole source of carbon and energy. All compounds listed were added as vapour. Plates were analysed for bacterial growth after 3-5 d. BP, biphenyl; Nah, naphthalene; IPB, isopropylbenzene; $m$-Cr, $m$-cresol; $o$-Cr, o-cresol; Tol, toluene; $\mathrm{C}_{4} \mathrm{Cl}$, 1-chlorobutane. + , Good growth; $+/-$, poor growth; - , no growth.

\begin{tabular}{|c|c|c|c|c|c|c|c|c|}
\hline \multirow[t]{2}{*}{ Strain } & \multirow{2}{*}{$\begin{array}{l}\text { Selection } \\
\text { substrate }\end{array}$} & \multicolumn{7}{|c|}{ Utilization of: } \\
\hline & & BP & $\mathrm{Nah}$ & IPB & $m-\mathrm{Cr}^{*}$ & $o-\mathrm{Cr}$ & Tol & $\mathrm{C}_{4} \mathrm{Cl}$ \\
\hline R. rhodochrous P200 & Nah & $+1-$ & + & - & $+1-$ & - & + & - \\
\hline Rbodococcus sp. Acr 33 & $m-\mathrm{Cr}$ & $+1-$ & + & - & + & - & $+/-$ & - \\
\hline Rbodococcus sp. A1 & $m-\mathrm{Cr}$ & $+1-$ & - & - & + & + & - & - \\
\hline Rbodococcus sp. $\mathrm{I} 1$ & $m-\mathrm{Cr}$ & $+1-$ & + & + & + & + & + & - \\
\hline R. erythropolis NCIMB $13065 \dagger$ & $\mathrm{C}_{4} \mathrm{Cl}$ & - & - & - & - & - & - & + \\
\hline Rhodococcus sp. NCIB 12038 & $\mathrm{Nah}$ & - & + & - & + & + & - & - \\
\hline
\end{tabular}

"Identical results were obtained when $p$-cresol was used as growth substrate.

†Benzene, phenol, coumarin and phenanthrene were also tested as growth substrates for NCIMB 13065 ; no growth with any of these compounds was detected. 
DNA sequencing. Plasmids pUC129 and pBluescript $\mathrm{KS}(+)$ with insertions containing extradiol dioxygenase genes were used as templates for the Taq Dye-Deoxy Terminator Cycle Sequencing kit (Applied Biosystems). DNA sequences were obtained using an automatic DNA sequencer (Applied Biosystems, model 373A). The nucleotide sequences of both strands were determined. Sequencing of PCR products was performed after template purification from agarose gels using corresponding PCR and/or internal primers. Primer synthesis was performed by Dr C. Stevenson (School of Biology and Biochemistry, The Queen's University of Belfast). Computer analysis of the sequences was performed using the DNASIS (Hitachi) software package. Alignment of the protein sequences was performed using the Higgins-Sharp algorithm (Higgins \& Sharp, 1988), and the TREECON program (Van de Peer \& De Wachter, 1994) was used for sequence analysis. Searches for nucleotide and amino acid sequence similarities were done by using the FASTA and BLAST programs (Pearson \& Lipman, 1988) in the EMBL and GenBank databases.

PCR. PCR primers were synthesized to amplify the internal parts of the cloned and sequenced R hodococcus dioxygenase genes. The primers were designed manually as well as by using the DNASIS package. Five sets of primers were so obtained: LK16, GAG GAC CCG AGC GGA ATC A (439-457 bp), and LK14, GAC CGC AGC GGC TAC GGG T (1071-1053 bp), producing an $e d o A$ PCR product of $633 \mathrm{bp}$; VD11, GGT TAC ATG GGC TTC GAG (54-71 bp), and VD14, CTC CGC CGA CTT CTC CAG (1149-1132 bp), producing an edoC PCR product of $1096 \mathrm{bp}$; LK33, CGC ATC GAG GCC ACC GAC (198-215 bp), and LK38, CGA CGG GTC CTC GAA CGT GA (503-484 bp), producing an $e d o B$ PCR product of 306 bp; LK33 and LK13, TCA GGT CGT TGA CGT GGC G (924-906 bp), producing an edoB PCR product of $727 \mathrm{bp}$; VD6, CTT CTA CAA GCT CAT GCC (1014-1032 bp), and VD3, CCG GTC GCT GCC TCG AGC (1416-1399 bp), producing an $e d o D$ PCR product of $403 \mathrm{bp}$. All primers were tested in PCR experiments using total DNA of the host strains from which corresponding dioxygenase genes were cloned. The authenticity of the products was confirmed by sequencing analysis.

Amplification of catechol dioxygenase gene sequences was done with Taq DNA polymerase (Stratagene) in a buffer supplied by the manufacturer. Reactions were carried out in volumes of $25 \mu \mathrm{l}$ or $50 \mu \mathrm{l}$ with concentrations of dNTPs at $200 \mu \mathrm{M}$ and primers at $0 \cdot 15 \mu \mathrm{M}$ each. The following temperature cycle was used for PCR: denaturation at $95^{\circ} \mathrm{C}$ for $3 \mathrm{~min}$ and then $95^{\circ} \mathrm{C}$ for $40 \mathrm{~s}, 60^{\circ} \mathrm{C}$ for $30 \mathrm{~s}, 72^{\circ} \mathrm{C}$ for $1 \mathrm{~min}$, for 30 cycles.

165 rRNA analysis. Amplification primers (27f, CCG AAT TCG TCG ACA ACA GAG TTT GAT CCT GGC TCA G; and 519r, GGG ATC CAA GCT TGT/A ATT ACC GCG GCG/T GCT G), located in the conserved region of the $16 \mathrm{~S}$ rRNA gene, were adapted from Schuppler et al. (1995). The following temperature profile was used for the PCR amplification: denaturation at $95{ }^{\circ} \mathrm{C}$ for $2 \mathrm{~min}$ and then $92{ }^{\circ} \mathrm{C}$ for $20 \mathrm{~s}, 50^{\circ} \mathrm{C}$ for $20 \mathrm{~s}, 72^{\circ} \mathrm{C}$ for $1 \mathrm{~min}$, for 30 cycles. PCR fragments were purified by agarose gel electrophoresis and the sequence of both strands was obtained as described previously. The partial 16S rDNA sequences (400 bp) were compared with all available $16 \mathrm{~S}$ rRNA sequences in the EMBL and GenBank databases using the program BLAST. Sequences were then aligned with sequences from representative R hodococcus spp. (EMBL and GenBank databases) using the DNASIS program. Distance matrices were produced by using the program treEcon (Van de Peer \& De Wachter, 1994) and trees were constructed by the neighbour-joining method with the same program. The reliability of tree nodes was analysed by bootstrapping. One hundred bootstrap trees were generated.

\section{RESULTS}

\section{Classification and initial characterization of Rhodococcus strains}

Partial $16 \mathrm{~S}$ rDNA sequences (400 bp) were obtained for six Rhodococcus strains and these sequences were used for alignment and phylogenetic analysis. This analysis confirmed previous classification of $R$. rhodochrous NCIMB 13064 and Rhodococcus erythropolis NCIMB 13065. Three strains isolated from a cresol-contaminated site (A1, I1 and Acr33) were all classified as Rhodococcus spp. They showed the closest relationship to Rhodococcus opacus and Rhodococcus marinonanscens; however, complete sequence analysis of $16 \mathrm{~S}$ rRNA genes and further taxonomic tests would probably be required for the final classification. The previously described naphthalene-degrading Rhodococcus sp. NCIB 12038 (Larkin \& Day, 1986) was also shown to be closely related to R. opacus, $R$. marinonanscens and $R$ bodococcus strains studied in this work.

The Rbodococcus strains were tested for use of a range of substrates as carbon and energy sources. The results of the utilization of some of the aromatic compounds as well as 1-chlorobutane are presented in Table 1. Each strain differed in its ability to utilize aromatic compounds and Rhodococcus sp. I1 possessed the widest substrate range of all the strains. R. erythropolis NCIMB 13065, which was isolated on 1-chloroalkane, did not grow on any of the aromatic compounds tested.

\section{Cloning of dioxygenase genes}

R. rhodochrous $\mathrm{P} 200$ and Rhodococcus sp. I1 were chosen for the cloning of catechol oxygenase genes. From the pUC129 library of Rhodococcus sp. I1 BamHI fragments, two positive clones were isolated from approximately $5 \times 10^{3}$ colonies sprayed with catechol and 3-methylcatechol. Fourteen positive clones were isolated from $2 \times 10^{4}$ clones of an $R$. rhodochrous $\mathrm{P} 200$ pUC129 library of BamHI fragments. Yellow colouration of differing intensities developed in clones after incubation of between 3 and $30 \mathrm{~min}$ at room temperature. Both I1 clones were investigated, i.e. pUI11 $(6.0 \mathrm{kbp}$ insert $)$ and pUI12 ( $3.2 \mathrm{kbp}$ insert). Positive clones obtained from the P200 library were analysed using Southern hybridization $\left(\right.$ at $65^{\circ} \mathrm{C}$ ) and three nonhomologous clones were chosen for further study. These clones were pUP25 (4.7 kbp insert), pUP22 ( $8 \mathrm{kbp}$ insert) and pUP210 ( $3.5 \mathrm{kbp}$ insert). Further analysis showed that the nucleotide sequence of pUP210 was $98 \%$ homologous to that of pUI12 (Rhodococcus sp. I1 clone).

Activities of the products of cloned dioxygenase genes against catechol and other compounds were determined 
Table 2. Activities expressed by cloned Rhodococcus dioxygenase genes in $E$. coli $\mathrm{DH} 5 \alpha$ cells

$\mathrm{DH} 5 \alpha$ cells with recombinant plasmids were grown in $2 \mathrm{YT}$ medium. Activities of the enzymes were measured in cell-free extracts. The results are expressed as a mean of triplicate experiments. CAT, catechol; 3MC, 3-methylcatechol; 4MC, 4-methylcatechol; 23DHB, 2,3-dihydroxybiphenyl; DHN, 1,2-dihydroxynaphthalene. Activities are expressed as a percentage of the activity in DH5 $\alpha$ (pUP25) cell-free extracts $(e d o A)$ when catechol was the substrate, which was defined as $100 \%$ [corresponds to $0.95 \mathrm{nmol} \min ^{-1}$ (mg protein $)^{-1}$.

\begin{tabular}{|llrrrrr|}
\hline Gene (host) & Plasmid & \multicolumn{5}{c|}{ Relative activity } \\
\cline { 3 - 7 } & & CAT & 3MC & 4MC & 23DHB & DHN \\
\hline edoA (P200) & pUP25 & 100 & 444 & 2 & 2884 & $<1$ \\
edoC (I1) & pUI11 & 13958 & 66316 & 1661 & 599684 & $<1$ \\
edoB (P200) & pUP22 & $<1$ & 323 & $<1$ & 3620 & $<1$ \\
edoD (I1) & pUI12 & 41 & 337 & 138 & 640 & $<1$ \\
$e d o D($ P200) & pUP210 & 12 & 72 & 27 & 150 & $<1$ \\
\hline
\end{tabular}

Table 3. Sequencing analysis of the Rhodococcus extradiol dioxygenase genes

DNA sequences were obtained using an automatic DNA sequencer (Applied Biosystems, model 373A). The nucleotide sequences of both strands were determined. Computer analysis of the sequences was performed using the DNASIS (Hitachi) software package. All four genes $(e d o A, e d o B, e d o C$ and $e d o D)$ are preceded by putative ribosome-binding sites (Shine \& Dalgarno, 1974).

\begin{tabular}{|lccccc|}
\hline Gene (plasmid) & Host strain & $\begin{array}{c}\text { Sequenced } \\
\text { fragment }(\mathbf{b p})\end{array}$ & Coding region (bp) & Putative protein (aa/Da) & Accession no. \\
\hline edoA (pUP25) & $\mathrm{P} 200$ & 1215 & $118-1072$ & $318 / 35435$ & L77225 \\
$e d o B$ (pUP22) & $\mathrm{P} 200$ & 1142 & $171-1071$ & $300 / 33506$ & GSDB:S:1050684 \\
$e d o C$ (pUI11) & $\mathrm{I} 1$ & 1338 & $36-987$ & $317 / 35014$ & GSDB:S:1076510 \\
$e d o D$ (pUI12) & $\mathrm{I} 1$ & 1995 & $844-1804$ & $320 / 34426$ & GSDB:S:1076511 \\
\hline
\end{tabular}

in cell-free extracts (Table 2). Surprisingly, 1,2-dihydroxynaphthalene dioxygenase activity was not detected in cell-free extracts of any clone obtained from strains P200 and I1, even though both strains utilized naphthalene as a growth substrate. However, all dioxygenases expressed activity against 2,3-dihydroxybiphenyl. Two genes encoding enzymes which expressed activities against catechol and 3-methylcatechol were designated $e d o A$ (pUP25) and $e d o C$ (pUI11). Two other genes which encoded enzymes with significantly lower (or no) activities against catechol than 3-methylcatechol were designated $e d o B$ (pUP22) and edoD (pUI12 and pUP210). In the case of $e d o B$ (plasmid pUP22), no activity was detected in $E$. coli cell-free extracts against catechol and 4-methylcatechol (Table 2).

\section{Nucleotide sequence analysis of dioxygenase genes}

The $e d o A, e d o B$ and $e d o D$ genes from $R$. rhodochrous NCIMB 13064, as well as edoC and $e d o D$ genes from Rhodococcus sp. I1, were sequenced. The results of the analysis of the Rhodococcus dioxygenase genes are summarized in Table 3 . The edoC gene showed high homology ( $98 \%$ identity) with Rhodococcus sp. RHA1 2,3-dihydroxybiphenyl dioxygenase I (Masai et al., 1995). Also, the nucleotide sequence of the edoC gene was identical to the $i p b C$ gene from the isopropylbenzene operon of R. erythropolis BD2 (Kesseler et al., 1996).

Several putative initiation codons in the same open reading frame (171-1071 bp) were found in the $1142 \mathrm{bp}$ fragment of pUP22 encoding the edoB dioxygenase (Table 3). The analysis of unidirectional deletions of plasmid pUP22 produced with exonuclease III showed that the ORF of the $e d o B$ gene probably started at position $171 \mathrm{bp}$ and encoded a protein of 300 aa with a calculated molecular mass of $33506 \mathrm{Da}$ (results not shown).

Highly homologous sequences of the $e d o D$ gene were found in clones from $R$. rhodochrous P200 and Rhodococcus sp. I1 (plasmids pUI12 and pUP210; $98 \%$ homology). Only the nucleotide sequence of the edoD gene from strain I1 obtained from the plasmid pUI12 has been deposited in the database (Table 2). Two ORFs were found in the $e d o D$ region with the positions bp 


\begin{tabular}{|c|c|c|c|}
\hline BphC & MS-IRSLGYMGFAVSDVAAWRS FLTQKLGLMEAGTTDNGDLF-RIDSRAW & 50 & \\
\hline EdoA & MALVTGIGYIGIGVSDLPAWEEF-AET IGFQIRERGEDGTLYLRMDKAHH & 50 & \\
\hline EdoC & MS-VQRLGYMGFEVADVPAWRAFMTEKLGAMEASSSENSARF-RIDSRSW & 50 & \\
\hline \multirow[t]{2}{*}{ EdoB } & MS-IRSLAYMRIEATDMAAWREYGLKVLGMVEGKGSDPDALYLRMDDFPA & 50 & \\
\hline & 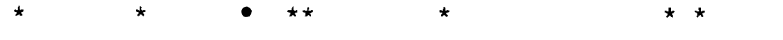 & & \\
\hline BphC & RIAVQQGEVDDLAFAGYEVADAAGLAQMADKLKQAGIAVTTGDASLARRR & 100 & \\
\hline EdoA & RVAVHPTGEDDLTYVGWQVADENGFDELERTLRAAGVPVEMAGEDDAELR & 100 & \\
\hline Edoc & RLMVEKGPSDDISLSGYEVESEDSLIAIKKRLEAHGIEVTTESGELADDR & 100 & \\
\hline \multirow[t]{2}{*}{ EdoB } & RLVI FPGEQDRLSVSGWETANAAELQEVRDNLSAAGVAFKEGTAEQLQDR & 100 & \\
\hline & 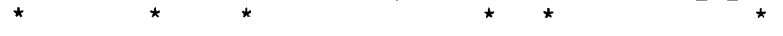 & & \\
\hline BphC & GVTGLITFADPFGLPLEIYYGASEVFEKPFLPGAAVSGFLTGEQGLGHEV & 150 & \\
\hline EdoA & GVARLMREEDPSGIKSEAYYGLVSEPEVPYVSPYAV-DFVTEDQGFGḦIV & 150 & \\
\hline EdoC & GVLGLISCTDTANTRVEIYYGATELFEKPFISPTGVSGFTTGDQGFGH̄YY & 150 & \\
\hline \multirow[t]{2}{*}{ EdoB } & RVDELIT FEDPSGNTLEAFHGAA-LEHRRVVSPYGHK-EVTGEQGLGĒ VV & 150 & \\
\hline & $\star \star \star * \quad * \quad * \quad * \quad * \star \star \star \star \star \bar{\star} \star$ & & \\
\hline BphC & RCVPDSDKALAFYTDVLGFQLSDVIDMKMG- - -PD-VTVPAYFLHCNE & 200 & \\
\hline EdoA & VMVDDYDETMRFYREVLGLQTSDLV--KVG-----AGGVQTRMAFMRCNP & 200 & \\
\hline EdoC & LAVPDIDAALDFYVKGLGFHLSDI IDWKLN----DE-LTVKLHFLHCNG & 200 & \\
\hline \multirow[t]{2}{*}{ EdoB } & LSTTDDEASLRFYRDVLGFRLRDSMRLPPQMVGRPADGKPAWLRFFGCNP & 200 & \\
\hline & 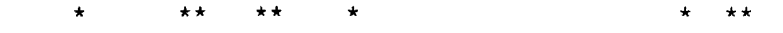 & & \\
\hline BphC & RHETTLAIAAFPLPKR I HEFFLEVASLDDVGFAFDRVDADGL-ITSTLGR븝 & 250 & \\
\hline EdoA & 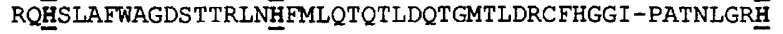 & 250 & \\
\hline EdoC & RHËTLALAGLPGAKKTHËFMLETKHMDDVGLAYDKFDADGT-VVMTLGR $\overline{\underline{H}}$ & 250 & \\
\hline \multirow[t]{2}{*}{ EdoB } & 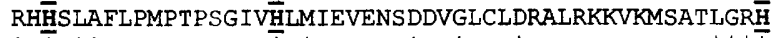 & 250 & \\
\hline & 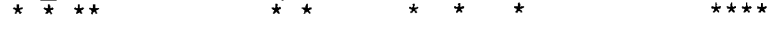 & & Fig. 1. Alignment of the dioxygenases \\
\hline BphC & TNDHMVSFYASTPSGVEVEYGWSARTVDRS-WVVVRHDSPSMWGHKSVRD & 300 & belonging to the type I, family 3 enzymes. \\
\hline EdoA & VNDYAVS F $\underline{\underline{Y}}$ ITTPSG FMIE Y YGWGVREVVSD-YPVDKYRSVS IWGHRNLDG & 300 & EdoA, EdoC and EdoB dioxygenases were \\
\hline Edoc & TNDHMLS FYY GAT PSG FAVEY YGWGARQVEPG-WSVVRYDKISIWGHKFVAE & 300 & analysed in this work; BphC is $P$. cepacia \\
\hline EdoB & VNDLMLS FȲMKTPGGFDIE FGCEGRQVEDESWIARESTAVSLWGHDFSVG & 300 & LB400 2,3-dihydroxybiphenyl dioxygenase \\
\hline & 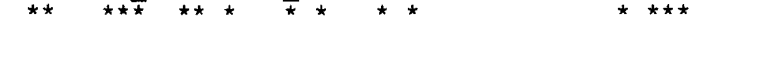 & & $\begin{array}{l}\text { (Hofer et al., 1993; accession no. X66122) of } \\
\text { the same family. Residues conserved in all }\end{array}$ \\
\hline BphC & K--A--- - - & 329 & four proteins are indicated by asterisks. The \\
\hline EdoA & IHYTQALPPEAAESPAEQHLVEEPVAAAV & 329 & conserved catalytic residues are given in \\
\hline EdoC & R--DRQVSSNAIEDELIDIDATLSAPAQA & 329 & bold and underlined. \\
\hline EdoB & MQ----- - - & 329 & \\
\hline
\end{tabular}

190-787 (ORF1) and bp 844-1804 (ORF2). On the basis of the analysis of exolII/S1 deletion derivatives of plasmid pUI12, ORF2 was shown to encode EdoD.

Amino acid sequences derived from the four dioxygenase genes were analysed. Alignment of EdoB, EdoA and EdoC with BphC LB400 2,3-dihydroxybiphenyl dioxygenase of Pseudomonas (Burkbolderia) cepacia LB400 (Hofer et al., 1993) of type I, family 3, for which X-ray structures have been analysed (Han et al., 1995), is shown in Fig. 1. This alignment shows that three metal-binding ligands, His-146, His-210 and Glu-260, and three additional active site residues, His-195, His241 and Tyr-250, of BphC LB400 are conserved in EdoB, EdoA and EdoC. The same degree of conservation was shown for all other type I extradiol dioxygenases (Eltis \& Bolin, 1996). It is important to note that the detected level of amino acid identity did not allow assignment of EdoB or EdoA into any of the five existing subfamilies of family 3. According to Eltis \& Bolin (1996), enzymes belonging to the same subfamilies in type I exhibit $\geqslant 54 \%$ amino acid identity, significantly higher than similarities observed in comparisons between EdoA, EdoB and other type I.3 extradiolic dioxygenases. Fig. 2 is a dendrogram showing relationships between the Rhodococcus Edo sequences and other type I.3 extradiolic dioxygenases; EdoA and EdoB represent two new proposed subfamilies ( $F$ and $G$ ).

EdoD (Rhodococcus sp. I1) showed $47 \%$ amino acid identity with the Mpc1 type II catechol 2,3-dioxygenase I from Alcaligenes eutrophus JMP222 (Kabisch \& Fortnagel, 1990), and since it does not show similarity with any of the type I enzymes, EdoD evidently belongs to the type II dioxygenases. The alignment of EdoD with two type II dioxygenases ( $\mathrm{Mpc} 1$ and $\mathrm{MhpB}$ ) and one recent entry found in the database is presented in Fig. 3, and shows conservation of amino acid residues in the regions 54-67 and 195-208 aa. These three dioxygenases may be considered as belonging to the same type II family (II.2). A much lower level of similarity was observed between the above enzymes and LigB, subunit B of protocatechuate 4,5-dioxygenase from Pseudomonas (Sphingomonas) paucimobilis (Noda et al., 1990). However, three histidines and four aspartates, which could possibly comprise the iron coordination sphere (Eltis \& Bolin, 1996), are conserved in all four sequences (Fig. 3).

\section{Distribution of extradiol dioxygenase genes in Rhodococcus strains}

DNA fragments containing Rbodococcus dioxygenase genes edoA $(1.2 \mathrm{~kb}$ fragment), edoC $(1.3 \mathrm{~kb})$, edo $B$ $(1.5 \mathrm{~kb})$ and $e d o D(1.4 \mathrm{~kb})$ were used as probes for hybridization with EcoRI and BamHI digests of total DNA obtained from all strains employed in this study. Internal primers designed on the basis of known 


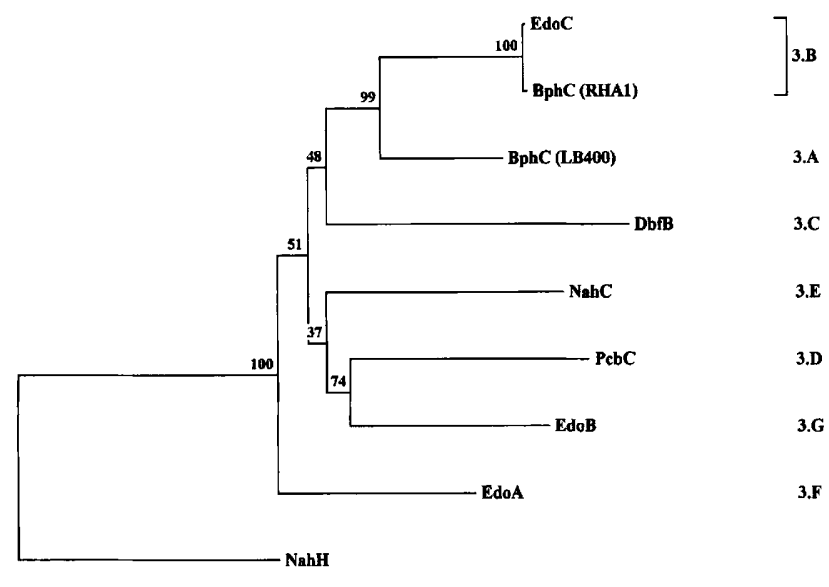

Fig. 2. Phylogram of the alignment of the family 3 (type I) extradiol dioxygenases. One enzyme from each of the five subfamilies (Eltis \& Bolin, 1996) is present. BphC (RHA1) Rhodococcus sp. RHA1 2,3-dihydroxybiphenyl dioxygenase (Masai et al., 1995; accession no. D32142); BphC (LB400), P. cepacia LB400 2,3-dihydroxybiphenyl dioxygenase (Hofer et al., 1993); DbfB, Sphingomonas paucimobilis RW1 2,2'3trihydroxybiphenyl dioxygenase (Happe et al., 1993; accession no. X72850); NahC, Pseudomonas putida PpG7 1,2dihydroxynaphthalene dioxygenase (Harayama \& Rekik, 1989; accession no. J04994); PcbC, Pseudomonas sp. DJ12 2,3dihydroxybiphenyl dioxygenase (Kim et al., 1996; accession no. D44550). EdoA, EdoC and EdoB dioxygenases were analysed in this work; $\mathrm{NahH}$, catechol 2,3-dioxygenase from P. putida PpG7 (Harayama et al., 1987; accession no. X06412), was used as an outgroup. Distance matrices were produced with the program TREECON (Van de Peer \& De Wachter, 1994) using Poisson correction (Zuckerkandl \& Pauling, 1965), and trees were constructed by the neighbour-joining method with the same program. The reliability of tree nodes was analysed by bootstrapping. One hundred bootstrap trees were generated. Abbreviations, e.g. 3.A, designate family (3) and subfamily (A) in accordance with Eltis \& Bolin (1996). Subfamilies 1.3.F and I.3.G are proposed by this study to contain EdoA and EdoB, respectively. Bootstrap values (\%) are indicated at the nodes.

sequences of $e d o A, e d o C, e d o B$ and $e d o D$ genes were used in PCR experiments to amplify the homologous sequences from the different Rhodococcus strains. The results of these experiments are presented in Table 4. The sizes of all PCR products corresponded to those obtained with DNA of strains P200 and I1 (hosts for cloned dioxygenase genes) and calculated from the sequence data. Complete nucleotide sequences of PCR fragments were obtained (633 nt for edoA; $727 \mathrm{nt}$ for $e d o B ; 1096 \mathrm{nt}$ for $e d o C$; and $403 \mathrm{nt}$ for edoD) and compared with the sequences of the genes cloned from strains P200 and I1. The results (Table 4) revealed that highly homologous sequences of extradiol dioxygenase genes were present in the Rhodococcus strains. Four of the six strains contained more than one edo sequence and sequences homologous to $e d o B$ were found in all six strains. It is interesting to note that $R$. erythropolis NCIMB 13065 contained an edoB-type sequence even though it could not utilize any of the aromatic compounds tested (Table 1). Sequences corresponding to edoA were found in four Rbodococcus strains, and only one gene $(e d o C)$ appeared to be uniquely represented; that is in strain I1.

\section{DISCUSSION}

Four Rhodococcus dioxygenase genes with activities against catechol and substituted catechols were cloned and sequenced. Only one gene $(e d o C)$ was shown to be homologous to previously analysed dioxygenases (Masai et al., 1995; Kesseler et al., 1996), being assigned to the I.3.B subfamily according to the classification scheme of Eltis \& Bolin (1996). The other three dioxygenase genes may be considered as essentially new in that they do not show high homology with any of the database entries. Amino acid sequences deduced from these genes were shown to have various degrees of homology to different extradiol dioxygenases. EdoA and EdoB were assigned to new subfamilies of the type I oxygenases (Eltis \& Bolin, 1996), and EdoD dioxygenase was a type II enzyme.

The Rhodococcus strains analysed in this work showed a remarkable diversity. Three different dioxygenase genes, belonging to two different types of these enzymes, were cloned from R. rhodochrous P200 and all four oxygenase sequences analysed were found in Rhodococcus sp. I1. The analysis of six Rhodococcus strains revealed that sequences homologous to $e d o A, e d o B$ and $e d o D$ were present in different $R$ hodococcus species. Only the $e d o C$ gene from Rhodococcus sp. I1 was not found in any of the other analysed strains (Table 4). Furthermore, this strain was the only one capable of utilizing isopropylbenzene, which, when considering the identity of $i p b C$ and $e d o C$, suggests that $e d o C$ belongs to the $i p b$ operon described previously (Kesseler $e t$ al., 1996). The edoD gene was cloned from two strains belonging to different species of Rhodococcus and sequences highly homologous to $e d o A$ were found in four different strains.

The most interesting of the genes analysed in this work was probably $e d o B$, which was found in all of the strains studied. A high degree of homology was found between the nucleotide sequence of this gene (cloned from strain P200) and corresponding PCR fragments obtained from the other Rhodococcus strains. The lowest homology observed was with NCIMB 13065 (Table 3). However, the translated amino acid sequence (obtained from a 900 bp PCR fragment, strain NCIMB 13065) exhibited $85 \%$ identity to that of the $e d o B$ gene. The finding of a gene homologous to $e d o B$ in $R$. erythropolis NCIMB 13065 is particularly noteworthy, since this strain was isolated as a 1-chloroalkane degrader and showed no ability to utilize any of the analysed aromatic compounds. The haloalkane dehalogenase (DhaA) of strain NCIMB 13064 was shown to be encoded by a $100 \mathrm{kbp}$ plasmid pRTL1 (Kulakova et al., 1995, 1997), and, remarkably, amongst a number of $\mathrm{Dha}^{-}$derivatives from this strain, two (P200 and P400) unexpectedly acquired the ability to utilize naphthalene as a sole carbon and energy source (Kulakova et al., 1996). The 


\begin{tabular}{|c|c|c|c|}
\hline EdoD & MTLALVCTSHSPLLEFNNPPPEVRTEVD-----RAFAQARQFIEEYDPD & 50 & \\
\hline MhpB & MHAYLHCLSHSPLVGYVDPAQEVLDEVN------GVIASARERIAAFSPE & 50 & \\
\hline Mpc1 & MPIQLECLSHTPLHGYVDPAPEVVAEVE------RVQAAARDRVRAFDPE & 50 & \\
\hline \multirow{2}{*}{ LigB } & MARVTTGITSSHIPALGAAIQTGTSDNDYWGPVFKGYQPIRDWIKQPGNM & 50 & \\
\hline & * $++++++\quad+++++\quad++* \quad+$ & & \\
\hline EdoD & L--VVSFAPDHYNGFFYKLMPSFCIGFEASGVGDFGSSA---GRLDVP-- & 100 & \\
\hline MhpB & I--VVLFAPDHYNGFFYDVMPPFCLGVGATAIGDFGSAA---GELPVP-- & 100 & \\
\hline Mpc1 & LFTVVVAPDHFNGFFYDVMPPFCIGAAATAIGDFKSLA---GKLPVP-- & 100 & \\
\hline \multirow[t]{2}{*}{ LigB } & PDVVI LVYNDHASAFDMNI I PT FAIGCAET----FKPADEGWGPRPVPDV & 100 & \\
\hline & $+*++++* *++*++\quad+* *+*+++*++\ldots+* *$ & & \\
\hline EdoD & ---SALAEQMAQSVLDQGVDIAVSL--EMEVDHGAVQPLEILLGGIATKP & 150 & \\
\hline MhpB & ---VELAEACAHAVMKSGIDLAVSYC--MQVDHGEAQPLEFLLGGLDKVP & 150 & \\
\hline Mpc1 & - -ADLALSLAESVMAADIDFTVALSHRMQVDHGCADALAALTGSLHRYP & 150 & \\
\hline \multirow{2}{*}{ LigB } & KGHPDLAWHIAQSL I LDEFDMT IM--NQMDVDHGCTVPLSMI FGEPEEWP & 150 & \\
\hline & $\star \star \star \star+*++\star \star \star \star \star \star *+*+*$ & & \\
\hline EdoD & --VIPI FVNSVAAPFAPMKRIRLLGEAVGTFLK--NFDGNVLILGSGGLS & 200 & \\
\hline MhpB & --VLPVFINGVATPLPGFQRTRMLGEAIGRFTS--TLNKRVLFLGSGGLS & 200 & \\
\hline Mpc1 & --VIPVEINSVAPPMATLRRARLLGDAVGRFLS FTRAGKRVLVVGSGGIS & 200 & \\
\hline \multirow[t]{2}{*}{ LigB } & CKVIPFPVNVVTYPPPSGKRCFALGDS IRAAVESFPEDLNVHVWGTGGMS & 200 & \\
\hline & 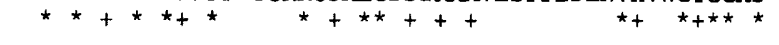 & & \\
\hline EdoD & HDPPVPRLEAATGEQRKMLLGCNHP-TAAARAVRQQRVIDTAKAF--TRG & 250 & \\
\hline MhpB & HQPPVPELAKADAHMRDRLLGSGKDLPASERELRQQRVISAAEKFV--ED & 250 & \\
\hline Mpc1 & HEPPVPEIAGASEEVAERLIA-GRN-PSPESAARQARTVAAAKS FVFTAG & 250 & \\
\hline \multirow[t]{2}{*}{ LigB } & HQ--- LQGPRAGLINK--- & 250 & \\
\hline & $\star{ }^{+}+++\star+\quad+$ & & \\
\hline EdoD & EAGIMDLAPEWDRQLLDILASGELERLDAWTAKEMAATAGNSAHEVRTWV & 300 & Fig. 3. Alignment of the type II \\
\hline MhpB & QRTLHPLNP IWDNQFMTLLEQGRIQELDAVSNEELSAIAGKSTHEIKTWV & 300 & dioxygenases. EdoD, extradiol dioxygenase \\
\hline Mpc1 & DSHLHPLNPEWDRAFLSLLASGELTAVDGMTNDAITRDGGKSAHE IRTWV & 300 & from Rhodococcus sp. 11 (this work); MhpB, \\
\hline \multirow[t]{2}{*}{ LigB } & $--\cdots-E F D L N F I D K L I S D P-E E L S K M P H I Q Y L R E S G S E G V E L V M W L$ & 300 & 3-(2,3-dihydroxyphenylpropionate) 1,2-di- \\
\hline & $+++^{\star} \quad{ }^{*}+t^{*}++^{\star}+t_{+}$ & & oxygenase of $E$. coli strain CS520 (accession \\
\hline EdOD & AAHNALK-AAAGQYTVTSEYYRPIPEYIAGFAV----- TTAVPVHKTA & 350 & no. X97450); $\mathrm{Mpc1}$, catechol 2,3-dioxy- \\
\hline MhpB & AAFAAIS--AFGNWRSEGRYYRPIPEWIAGFG---_- & 350 & genase I from Alcaligenes eutrophus \\
\hline Mpc1 & AAFGALAFFTAYGPYRASLDFYRAIPEWIAGFA-- & 350 & JMP222 (Kabisch \& Fortnagel, 1990); LigB, \\
\hline \multirow[t]{3}{*}{ LigB } & IMRGALPEKVRDLYT----FYH-IPASNTALGAMILQPEETAGTPLEPRK & 350 & subunit $B$ of protocatechuate $4,5-$ \\
\hline & $++x^{2}+{ }^{*} x^{*}+++++$ & & dioxygenase from $P$. paucimobilis (Noda et \\
\hline & GLR-------- & 360 & al., 1990). The amino acid residues identical \\
\hline MhpB & EN---.---- & 360 & in all sequences are indicated by asterisks \\
\hline Mpcl & AAV-....-.- & 360 & and those identical only in the dioxygenases \\
\hline LigB & VMSGHSLAQA & 360 & of the family II. 2 are indicated by + . \\
\hline
\end{tabular}

Table 4. Distribution of dioxygenase gene sequences in Rhodococcus strains

Dioxygenase gene sequences were amplified by PCR as described in Methods. Southern hybridization was carried out at $65^{\circ} \mathrm{C}$. + , Dioxygenase sequence was detected in hybridization experiments and PCR product obtained; - , no homologous sequence was found. PCR fragments produced were sequenced and the nucleotide sequences were analysed. Percentage similarities of the sequences by comparison with the corresponding genes (edoA and edo $B$ from $R$. rhodochrous $\mathrm{P} 200$; $e d o C$ and $e d o D$ from $R$ bodococcus sp. I1) are given in parentheses.

\begin{tabular}{|lcccc|}
\hline Strain & \multicolumn{4}{c|}{ Sequence (percentage homology) } \\
\cline { 2 - 5 } & edoA & edoC & edoB & edoD \\
\hline R. rhodochrous P200 & $+(100)$ & - & $+(100)$ & $+(98)$ \\
Rhodococcus sp. I1 & $+(95)$ & $+(100)$ & $+(100)$ & $+(100)$ \\
Rhodococcus sp. A1 & $+(90)$ & - & $+(97)$ & - \\
Rhodococcus sp. Acr33 & $+(95)$ & - & $+(99)$ & - \\
R. erythropolis NCIMB 13065 & - & - & $+(85)$ & - \\
Rhodococcus sp. NCIB 12038 & - & - & $+(91)$ & - \\
\hline
\end{tabular}

$\mathrm{Nah}^{+}$phenotype in these derivatives appeared to be fairly stable; however, $\mathrm{Dha}^{+}$revertants, which arose at a frequency of about $10^{-8}$, had lost the ability to utilize naphthalene (Kulakova et al., 1996). These results may suggest the presence of cryptic biodegradation pathways in Rhodococcus species. So far we have not been able to relate the dioxygenase genes $e d o A, e d o B$ and $e d o D$ to specific aromatic degradation pathways. 


\section{ACKNOWLEDGEMENTS}

This project was supported by The Queen's University Environmental Science and Technology Research Centre and DENI Cast studentship to V.A.D. in collaboration with the Electricity Supply Board of Ireland.

We are thankful to Dr J. R. Rao for the help with $16 \mathrm{~S}$ rRNA sequencing and Dr Clark Stevenson for the synthesis of sequencing primers. We are grateful to Professor Masao Fukuda (Nagaoka University of Technology, Japan) for the gift of 2,3-dihydroxybiphenyl. We are indebted to Professor W. J. Swindall for the support and encouragement of this work.

\section{REFERENCES}

Asturias, J. A., Eltis, L. D., Prucha, M. \& Timmis, K. N. (1994). Analysis of three 2,3-dihydroxybiphenyl 1,2-dioxygenases found in Rbodococcus globerulus P6.J Biol Chem 269, 7807-7815.

Curragh, H., Flynn, O., Larkin, M. J., Stafford, T. M., Hamilton, J. T. G. \& Harper, D. B. (1994). Haloalkane degradation and assimilation by Rhodococcus rhodochrous NCIMB 13064 Microbiology 140, 1433-1442.

Eltis, L. D. \& Bolin, J. T. (1996). Evolutionary relationship among extradiol dioxygenases. J Bacteriol 178, 5930-5937.

Finnerty, W. R. (1992). The biology and genetics of the genus Rhodococcus. Annu Rev Microbiol 46, 193-218.

Gibson, D. T. (1971). Assay of enzymes of aromatic metabolism. Methods Microbiol 6, 463-478.

Han, S., Eltis, L. D., Timmis, K. N., Muchmore, S. W. \& Bolin, J. T. (1995). Crystal structure of biphenyl-cleaving extradiol dioxygenase from PCB-degrading pseudomonad. Science 270, 976-980.

Happe, B., Eltis, L. D., Poth, H., Hedderich, R. \& Timmis, K. N. (1993). Characterization of 2,2',3-trihydroxybiphenyl dioxygenase, an extradiol dioxygenase from the dibenzofuran- and dibenzo-p-dioxin-degrading bacterium Sphingomonas sp. strain RW1. J Bacteriol 175, 7313-7320.

Harayama, S. \& Rekik, M. (1989). Bacterial aromatic ring-cleavage enzymes are classified in two different gene families. J Biol Chem 264, 15328-15333.

Harayama, S., Rekik, M., Wasserfallen, A. \& Bairoch, A. (1987). Evolutionary relationships between catabolic pathways for aromatics: conservation of gene order and nucleotide sequences of catechol oxidation genes of pWW0 and NAH7 plasmids. Mol Gen Genet 210, 241-247.

Harayama, S., Kok, M. \& Neidle, E. L. (1992). Functional and evolutionary relationships among diverse dioxygenases. Annu Rev Microbiol 46, 565-601.

Hauschild, J. E., Masai, E., Sugiyama, K., Hatta, T., Kimbara, K., Fukuda, M. \& Yano, K. (1996). Identification of an alternative 2,3dihydroxybiphenyl 1,2-dioxygenase in Rbodococcus sp. strain RHA1 and cloning of the gene. Appl Environ Microbiol 62, 2940-2946.

Hayaishi, 0. (1974). Molecular Mechanism of Oxygen Activation. New York: Academic Press.

Higgins, D. G. \& Sharp, P. M. (1988). Clustal: a package for performing multiple sequence alignments on a microcomputer. Gene 73, 237-244.

Hofer, B., Eltis, L. D., Dowling, D. N. \& Timmis, K. N. (1993). Genetic analysis of a Pseudomonas locus encoding a pathway for biphenyl/polychlorinated biphenyl degradation. Gene 130, 47-55.

Kabisch, M. \& Fortnagel, P. (1990). Nucleotide sequence of metapyrocatechase I (catechol 2,3-oxygenase) gene mpc1 from Alcaligenes eutrophus JMP222. Nucleic Acids Res 18, 3405-3406.

Keen, N. T., Tamaki, S., Kobayashi, D. \& Trollinger, D. (1988). Improved broad-host-range plasmids for DNA cloning in Gramnegative bacteria. Gene 70, 191-197.

Kesseler, M., Dabbs, E. R., Averhoff, B. \& Gottschalk, G. (1996). Studies on the isopropylbenzene 2,3-dioxygenase and 3-isopropylcatechol 2,3-dioxygenase genes encoded by the linear plasmid of Rhodococcus erythropolis BD2. Microbiology 142, 3241-3251.

Kim, E., Kim, Y. \& Kim, C.-K. (1996). Genetic structures of genes encoding 2,3-dihydroxybiphenyl 1,2 dioxygenase and 2-hydroxy6-oxo-6-phenylhexa-2,4-dienoic acid hydrolase from biphenyland 4-chlorobiphenyl-degrading Pseudomonas sp. strain DJ-12. Appl Environ Microbiol 62, 262-265.

Kuhm, A. E., Stolz, A., Ngai, K.-L. \& Knackmuss, H. J. (1991) Purification and characterization of a 1,2-dihydroxynaphthalene dioxygenase from a bacterium that degrades naphthalenesulfonic acids. J Bacteriol 173, 3795-3802.

Kulakova, A. N., Stafford, T. M., Larkin, M. J. \& Kulakov, L. A. (1995). Plasmid pRTL1 controlling 1-chloroalkane degradation by Rhodococcus rhodochrous NCIMB13064. Plasmid 33, 208217.

Kulakova, A. N., Reid, K. A., Larkin, M. J., Allen, C. C. R. \& Kulakov, L. A. (1996). Isolation of Rhodococcus rbodochrous NCIMB13064 derivatives with new biodegradative abilities. FEMS Microbiol Lett 145, 227-231.

Kulakova, A. N., Larkin, M. J. \& Kulakov, L. A. (1997). The plasmid-located haloalkane dehalogenase gene from Rbodococcus rhodochrous NCIMB 13064. Microbiology 143, 109-115.

Larkin, M. J. \& Day, M. J. (1986). The metabolism of carbaryl by three bacterial isolates, Pseudomonas spp. (NCIB12042 and 12043) and Rhodococcus sp. (NCIB12038) from garden soil. $J$ Appl Bacteriol 60, 233-242.

Maeda, M., Chung, S.-Y., Song, E. \& Kudo, T. (1995). Multiple genes encoding 2,3-dihydroxybiphenyl 1,2-dioxygenase in the Gram-positive polychlorinated biphenyl degrading bacterium Rhodococcus erythropolis TA421, isolated from termite ecosystem. Appl Environ Microbiol 61, 549-555.

Masai, E., Yamada, A., Healey, J. M., Hatta, T., Kimbara, K., Fukuda, M. \& Yano, K. (1995). Characterization of biphenyl catabolic genes of Gram-positive polychlorinated biphenyl degrader Rhodococcus sp. strain RHA1. Appl Environ Microbiol 61, 2079-2085.

Miller, J. H. (1972). Experiments in Molecular Genetics. Cold Spring Harbor, NY : Cold Spring Harbor Laboratory.

Noda, Y., Nishikawa, S., Shozuka, K.-I., Kadokura, H., Nakajima, H., Yoda, K., Katayama, Y., Morohoshi, N., Haraguchi, T. \& Yamasaki, M. (1990). Molecular cloning of protocatechuate 4,5dioxygenase genes of Pseudomonas paucimobilis. J Bacteriol 172, 2704-2709.

Patel, T. R. \& Barnsley, E. A. (1980). Naphthalene metabolism by pseudomonads: purification and properties of 1,2-dihydroxynaphthalene oxygenase. J Bacteriol 143, 668-673.

Pearson, W. R. \& Lipman, D. J. (1988). Improved tools for biological sequence comparison. Proc Natl Acad Sci USA 85, 2444-2448.

Sambrook, J., Fritsch, E. F. \& Maniatis, T. (1989). Molecular Cloning: a Laboratory Manual, 2nd edn. Cold Spring Harbor, NY: Cold Spring Harbor Laboratory.

Schuppler, M., Mertens, F., Schön, G. \& Göbel, U. B. (1995). Molecular characterization of nocardioform actinomycetes in 
activated sludge by $16 \mathrm{~S}$ rRNA analysis. Microbiology 141 , 513-521.

Shine, J. \& Dalgarno, L. (1974). The 3 'terminal sequence of Escherichia coli $16 \mathrm{~S}$ ribosomal RNA: complementarity to nonsense triplets and ribosomal binding sites. Proc Natl Acad Sci USA 71, 1342-1346.

Van de Peer, Y. \& De Wachter, R. (1994). TREECON for Windows: a software package for the construction and drawing of evolutionary trees for the Microsoft Windows environment. Comput Appl Biosci 10, 569-570.

Zuckerkandl, E. \& Pauling, L. (1965). Evolutionary divergence and convergence in proteins. In Evolving Genes and Proteins, pp. 97-166. Edited by V. Bruson \& H. J. Vogel. New York: Academic Press.

Zukowski, M. M., Gaffiney, D. F., Speck, D., Kauffman, M., Findeli, A., Wisecup, A. \& Lecocq, J.-P. (1983). Chromogenic identification of genetic regulatory signals in Bacillus subtilis based on expression of a cloned Pseudomonas gene. Proc Natl Acad Sci USA 80, 1101-1105.

Received 17 March 1997; revised 21 July 1997; accepted 12 January 1998 